\title{
ORIGINAL
}

\section{Positional distribution of fatty acids in phosphatidylcholine and phosphatidylethanolamine from rat sublingual salivary gland}

\author{
Koji Yashiro, Yasunaga Kameyama, Masako Mizuno, \\ Akihiko Okada, Takehisa Takenaka * and Yutaka Yokota \\ Department of Oral Biochemistry \\ (Chief: Prof. Yutaka Yokota) \\ ${ }^{*}$ Department of Endodontics \\ (Chief: Prof. Yoshiyuki Mukoyama) \\ Asahi University School of Dentistry, 1851-1 Hozumi, \\ Motosu, Gifu 501-02, Japan
}

[Accepted for publication: November 11, 1987]

\begin{abstract}
Key words : Phosphatidylcholine/ phosphatidylethanolamine / fatty acid/isoproterenol / rat sublingual gland
\end{abstract}

\begin{abstract}
The $s n \cdot 1$ position of phosphatidylcholine from rat sublingual gland was highly occupied by saturated fatty acids, palmitate and stearate. Arachidonate and linoleate were exclusively located at the $s n-2$ position. Such asymmetry was also observed in phosphatidylethanolamine, although considerable amounts of alkenyl moieties were present at the $s n-1$ position. Based on their contents, it was suggested that the most abundant molecular species of phosphatidylcholine and phosphatidylethanol. amine are 1-palmitoyl-2-arachidonoyl and 1-stearoyl-or 1-alkenyl-2-arachidonoyl (plasmalogen) types, respectively. Chronic administration of isoproterenol which causes an increase of linoleoyl-phospholipids in parotid and submandibular glands did not affect the positional distribution of fatty acids in phosphatidylcholine and phosphatidylethanolamine from the sublingual gland.
\end{abstract}

\section{Introduction}

Salivary glands respond to various stimuli resulting in saliva secretion ${ }^{11}$. Among three major glands (sublingual, submandibular and parotid), the sublingual gland shows characteristic features different from other two. There are many reports describing that saliva secretion from sublingual gland is unresponsive to sympathomimetic agents such as isoproterenol in contrast to submandibular and parotid glands $^{1,2)}$. In our comparative studies on membrane phospholipids in three glands of rats, their fatty acyl compositions, especially those of fatty acids having a carbon-chain length of eighteen, in the sublingual gland were also different from those in other glands ${ }^{3}$. On the other hand, one of the major membrane constituents, phospholipids, may have im- portant roles not only in the physical structure but also in various physiological functions of cells such as receptor-mediated transmembrane signaling ${ }^{4,5)}$ and membrane-bound or embedded enzyme actions ${ }^{6,7)}$. In spite of these characteristics, no detailed information has been reported about sublingual gland phospholipids. In this communication, we analyzed the positional distribution of fatty acyl moieties in major phospholipids, phosphatidylcholine and phosphatidylethanolamine, of the rat sublingual gland. Effects of chronic administration of isoproterenol on the acyl compositions were also examined.

\section{Materials and Methods}

Materials

Snake venom from Crotalus adamanteus and Naja naja kaouthia, and DL-isoprote- 
renol hydrochloride were purchased from Sigma Chemical Co., St. Louis, Missouri. Precoated silica plates (Silica Gel 60) for thin-layer chromatography (TLC) were obtained from E. Merck, Darmstadt. Fatty acid methyl ester standards were of $\mathrm{Nu}$-ChekPrep, Inc., Elysian, Minnesota.

\section{Animals and their treatment}

Eighteen male Sprague-Dawley rats, 8-9 weeks old, were used. They were maintained ad libitum on water and commercial solid chow. Half of the animals received intraperitoneal injection of $25 \mathrm{mg} / \mathrm{kg}$. body weight of isoproterenol as a $30 \mathrm{mg} / \mathrm{m} l$ solution once a day for 10 days $^{8}$. Twenty hours after the last injection all animals were killed by exsanguination. Sublingual glands were removed and carefully freed from adipose tissue, blood vessels and capsule.

\section{Lipid analysis}

The tissue was cut into small pieces and homogenized with a Potter-Elvehjem Teflonpestle homogenizer in $4 \mathrm{vol}$. ( $\mathrm{v} / \mathrm{w}$ ) of ice-cold water. A total lipid extract was obtained from the homogenate as described by Bligh and Dyer ${ }^{9)}$ in the presence of 2,6-di-tertbutyl-4-methylphenol (butylated hydroxytoluene, BHT) as an anti-oxidant $(0.005 \%, \mathrm{w} / \mathrm{v})$. Phosphatidylcholine and phosphatidylethanolamine were separated by two-dimensional TLC on a $2.5 \%$ magnesium acetate-treated silica gel plate using the following solvent systems ; chloroform/methanol/13.5N ammonia water $(65: 35: 7, \mathrm{v} / \mathrm{v})$ for the first dimension, and chloroform/acetone/methanol/acetic acid/water $(6: 8: 2: 2: 1, \mathrm{v} / \mathrm{v})$ for the second dimension ${ }^{3,81}$. Separated phosphatidylcholine and phosphatidylethanolamine were hydrolyzed with venom phospholipase $\mathrm{A}_{2}$ (Crotalus adamanteus venom for phosphatidylcholine and Naja naja kaouthia for phosphatidylethanolamine) as described previously ${ }^{10}$. The hydrolyzates of phospholipid were chromatographed on a TLC plate in chloroform/ methanol/water $(65: 25: 4, \mathrm{v} / \mathrm{v})$ to about three quarters of the way up the plate. The plate was then developed to its full length in diethyl ether/petroleum ether/acetic acid (30: $80: 1, \mathrm{v} / \mathrm{v}$ ) for the complete separation of fatty acids formed by the hydrolysis from BHT. The liberated fatty acids ( $s n-2$ position) and the fatty acyl and alkenyl groups of the lysophospholipid ( $s n$-1 position) were methylated with $15 \% \mathrm{BF}_{3}$-methanol as described by Morrison and Smith ${ }^{11}$, and analyzed by gas chromatography (Shimadzu GC-9A) as described previously ${ }^{8}$. The chromatogram peaks were identified by comparison of their retention times with standards.

\section{Results}

Positional distribution of fatty acids in phosphatidylcholine and phosphatidylethanol. amine from rat sublingual gland

Fatty acid positional distributions of two major phospholipids in sublingual gland, phosphatidylcholine and phosphatidylethanol. amine, are summarized in Table 1. A good stoichiometry between these patterns and overall compositions of fatty acids described in our previous paper ${ }^{\text {y' }}$ was obtained. The most abundant fatty acid at the $s n-1$ position of phosphatidylcholine was palmitic acid followed by stearic acid. The sum of the two saturated fatty acids was about $80 \%$ of the total at the $s n-1$ position. In contrast, $s n-2$ position was highly occupied by unsaturated fatty acids such as arachidonic, linoleic and oleic acids. Especially, arachidonic and linoleic acids were exclusively located at the $s n-2$ position. These tendencies of fatty acid asymmetric distribution were also observed in phosphatidylethanolamine although stearic acid was the highest at the $s n$-1 position. However, considerable amounts (25 $\%$ of the total) of dimethyl acetals derived from vinyl ether-linked moieties were detected at the $s n-1$ position of phosphatidylethanolamine.

Positional distribution of fatty acids in phosphatidylcholine and phosphatidylethanolamine from isoproterenol-treated rat sub. lingual gland

In our previous paper ${ }^{8)}$, it was demonstrated that the chronic administration of isoproterenol induced an alteration of phospholipid compositions including a significant increase of phosphatidylcholine in all of the three major salivary glands. Therefore, the effects of isoproterenol on the fatty acid positional distribution of major membrane phospho. lipids, phosphatidylcholine and phosphatidyl. 
Table 1 Positional distribution of fatty acids in phosphatidylcholine and phosphatidylethanolamine from rat sublingual gland

\begin{tabular}{|c|c|c|c|c|}
\hline \multirow{2}{*}{ Fatty acid } & \multicolumn{2}{|c|}{ Phosphatidylcholine } & \multicolumn{2}{|c|}{ Phosphatidylethanolamine } \\
\hline & $\begin{array}{c}s n-1 \\
\text { position }\end{array}$ & $\begin{array}{c}s n-2 \\
\text { position }\end{array}$ & $\begin{array}{c}s n-1 \\
\text { position }\end{array}$ & $\begin{array}{c}s n-2 \\
\text { position } \\
\end{array}$ \\
\hline $\mathrm{C} 14: 0$ & $0.7 \pm 0.05$ & $0.7 \pm 0.04$ & $0.1 \pm 0.01$ & $0.7 \pm 0.14$ \\
\hline C $16: 0-\mathrm{DMA}^{*}$ & $0.1 \pm 0.01$ & $0.1 \pm 0.01$ & $15.1 \pm 0.39$ & $0.2 \pm 0.04$ \\
\hline $\mathrm{C} 16: 0$ & $55.4 \pm 0.48$ & $14.4 \pm 0.35$ & $13.2 \pm 0.08$ & $4.7 \pm 0.15$ \\
\hline $\mathrm{C} 16: 1$ & $1.5 \pm 0.04$ & $1.7 \pm 0.04$ & $1.3 \pm 0.04$ & $1.9 \pm 0.35$ \\
\hline C $18: 0-\mathrm{DMA}^{*}$ & N D & N D & $8.7 \pm 1.10$ & $0.2 \pm 0.02$ \\
\hline C $18: 0$ & $21.4 \pm 0.28$ & $2.1 \pm 0.53$ & $36.3 \pm 0.11$ & $4.0 \pm 0.59$ \\
\hline C $18: 1$ & $9.7 \pm 0.03$ & $13.7 \pm 0.55$ & $13.6 \pm 0.10$ & $14.4 \pm 0.62$ \\
\hline $\mathrm{C} 18: 2$ & $2.5 \pm 0.20$ & $20.6 \pm 0.59$ & $1.3 \pm 0.09$ & $9.4 \pm 1.53$ \\
\hline $\mathrm{C} 20: 3$ & $0.2 \pm 0.01$ & $4.8 \pm 0.20$ & $0.1 \pm 0.01$ & $3.3 \pm 0.20$ \\
\hline $\mathrm{C} 20: 4$ & $0.7 \pm 0.02$ & $34.2 \pm 0.58$ & $2.4 \pm 0.15$ & $46.0 \pm 0.81$ \\
\hline $\mathrm{C} 20: 5$ & $0.2 \pm 0.03$ & $0.1 \pm 0.01$ & $0.2 \pm 0.01$ & $0.8 \pm 0.33$ \\
\hline $\mathrm{C} 22: 5$ & $0.1 \pm 0.01$ & $0.4 \pm 0.01$ & $0.1 \pm 0.03$ & $1.4 \pm 0.03$ \\
\hline C $22: 6$ & $0.2 \pm 0.01$ & $0.8 \pm 0.03$ & $0.4 \pm 0.02$ & $4.6 \pm 0.12$ \\
\hline $\mathrm{C} 24: 0$ & $0.1 \pm 0.01$ & $1.9 \pm 0.09$ & $<0.05$ & $2.0 \pm 0.01$ \\
\hline Others & 7.3 & 4.5 & 7.2 & 6.4 \\
\hline
\end{tabular}

The results represent the means (weight $\%) \pm \mathrm{SE}$ of three separate experiments. Fatty acids are designated by the number of carbon atoms and double bonds.

* Dimethyl acetal.

$\mathrm{ND}=$ not detectable.

ethanolamine, were examined in the sublingual gland. As shown in Table 2, fatty acid composition of each position in sublingual gland phosphatidylcholine and phosphatidylethanolamine was not affected by isoproterenol treatment. Differences from control values (Table 1) were not significant $(p<0.01)$ by Student's $t$-test with the exception of stearic acid at the $s n-2$ position of phosphatidylethanolamine. However, its difference was only $0.9 \%$.

\section{Discussion}

Although it is thought that membrane phospholipids in various cells have important roles for physical and physiological functions of cells ${ }^{4-7}$, less is known about sublingual gland phospholipids ${ }^{3,8}$. In this study, therefore, we analyzed phospholipid fatty acyl composition in rat sublingual gland in detail. The results from phospholipid fatty acid analysis suggest that the most abundant molecular species of phosphatidylcholine and phosphatidylethanolamine in rat sublingual gland are 1-palmitoyl-2-arachidonoyl and 1-stearoylor 1-alkenyl-2-arachidonoyl (plasmalogen) types, respectively. It is worth noting that phosphatidylethanolamine contained a large amount of arachidonate which is a precursor of prostaglandins and leukotrienes. In some cells, especially in macrophages and neutrophils, 1-alkenyl type of phosphatidylethanolamine is highly occupied at the $s n-2$ position by arachidonate ${ }^{12,13)}$. It can be considered that phosphatidylethanolamine including ethanolamine plasmalogen is a possible source of arachidonate.

In several tissues, unsaturated fatty acyl moieties at the $s n-2$ position of phospholipid are introduced via deacylation-reacylation cycles $^{14}$. In our previous investigation ${ }^{15}$, the presence of 1-acyl-glycerophosphocholine acyltransferase activity was shown in sublingual gland microsomes. This enzyme activity of sublingual gland for saturated acyl-CoAs (palmitoyl-and stearoyl-CoAs) is lower than an unsaturated one, oleoyl-CoA, the same as the enzyme characteristics in liver and other salivary gland microsomes. Therefore, there may be a relationship between the high content of unsaturated fatty acyl components at 
Table 2 Positional distribution of fatty acids in phosphatidylcholine and phosphatidylethanolamine from isoproterenol-treated rat sublingual gland

\begin{tabular}{|c|c|c|c|c|}
\hline \multirow{2}{*}{ Fatty acid } & \multicolumn{2}{|c|}{ Phosphatidylcholine } & \multicolumn{2}{|c|}{ Phosphatidylethanolamine } \\
\hline & $\begin{array}{c}s n-1 \\
\text { position }\end{array}$ & $\begin{array}{c}s n-2 \\
\text { position }\end{array}$ & $\begin{array}{c}s n-1 \\
\text { position }\end{array}$ & $\begin{array}{c}s n-2 \\
\text { position } \\
\end{array}$ \\
\hline $\mathrm{C} 14: 0$ & $0.9 \pm 0.09$ & $1.2 \pm 0.32$ & $0.2 \pm 0.01$ & $0.9 \pm 0.38$ \\
\hline C16:0-DMA* & $0.2 \pm 0.04$ & $0.3 \pm 0.05$ & $15.8 \pm 0.60$ & $0.4 \pm 0.11$ \\
\hline C16:0 & $54.5 \pm 0.39$ & $13.2 \pm 0.64$ & $12.8 \pm 0.28$ & $4.4 \pm 0.93$ \\
\hline $\mathrm{C} 16: 1$ & $1.6 \pm 0.17$ & $2.3 \pm 0.26$ & $1.3 \pm 0.03$ & $2.0 \pm 0.45$ \\
\hline C 18:0-DMA* & ND & ND & $9.3 \pm 0.41$ & $0.4 \pm 0.09$ \\
\hline $\mathrm{C} 18: 0$ & $20.8 \pm 0.15$ & $1.9 \pm 0.55$ & $35.4 \pm 0.09$ & $3.2 \pm 0.36$ \\
\hline $\mathrm{C} 18: 1$ & $9.8 \pm 0.15$ & $14.2 \pm 0.78$ & $12.6 \pm 0.21$ & $13.8 \pm 0.43$ \\
\hline $\mathrm{C} 18: 2$ & $2.3 \pm 0.06$ & $19.5 \pm 0.77$ & $1.6 \pm 0.04$ & $8.1 \pm 0.12$ \\
\hline $\mathrm{C} 20: 3$ & $0.2 \pm 0.01$ & $5.4 \pm 0.36$ & $0.1 \pm 0.01$ & $3.6 \pm 0.22$ \\
\hline C $20: 4$ & $0.7 \pm 0.04$ & $31.5 \pm 1.39$ & $2.5 \pm 0.19$ & $45.2 \pm 1.71$ \\
\hline $\mathrm{C} 20: 5$ & $0.5 \pm 0.33$ & $1.2 \pm 0.49$ & $0.5 \pm 0.07$ & $0.8 \pm 0.46$ \\
\hline$C 22: 5$ & $0.1 \pm 0.01$ & $0.5 \pm 0.02$ & $0.1 \pm 0.01$ & $1.3 \pm 0.07$ \\
\hline $\mathrm{C} 22: 6$ & $0.3 \pm 0.01$ & $0.9 \pm 0.10$ & $0.4 \pm 0.06$ & $6.8 \pm 0.46$ \\
\hline $\mathrm{C} 24: 0$ & $0.1 \pm 0.02$ & $1.4 \pm 0.11$ & $0.2 \pm 0.11$ & $1.7 \pm 0.12$ \\
\hline Others & 8.1 & 6.5 & 7.2 & 7.4 \\
\hline
\end{tabular}

The results represent the means (weight $\%) \pm \mathrm{SE}$ of three separate experiments. Fatty acids are designated by the number of carbon atoms and double bonds.

* Dimethyl acetal.

$\mathrm{ND}=$ not detectable.

the $s n$-2 position of phosphatidylcholine and the reacylating enzyme activity. On the other hand, in order to explain the characteristic positional distribution of fatty acids in phosphatidylcholine and phosphatidylethanolamine especially that of $s n-1$ position, the common de novo acylating enzyme activity, glycerophosphate acyltransferase, should be examined by various saturated and unsaturated fatty acyl-CoAs.

Positional distribution of fatty acids in each phosphatidylcholine and phosphatidylethanolamine from the isoproterenol-treated rat was almost the same as the control. These results support the previous observations ${ }^{8}$ that the overall fatty acyl compositions of phosphatidylcholine and phosphatidylethanolamine from rat sublingual gland were not changed by isoproterenol treatment, and strongly suggest that this changelessness of fatty acids is not due to the rearrangement of phospholipid fatty acyl moieties within the $s n-1$ and the $s n-2$ positions. In parotid and submandibular glands, on the other hand, fatty acid compositions of phosphatidylcholine and phosphatidylethanolamine were remarkably changed by the treatment accompanied with a gland enlargement as described previously ${ }^{8}$. It is well known that the sublingual gland is not affected by chronic administration of isoproterenol morphologically ${ }^{8,16}$ and does not respond to the agonist in saliva secretion ${ }^{1,2}$ in contrast to the other two salivary glands; adrenergic nerve terminals in sublingual gland are found only adjacent to the blood vessels ${ }^{17}$. Therefore, the fatty acid modifications might be coupled with beta-adrenergic stimulation induced by the drug.

\section{Acknowledgments}

We are thankful to Mrs. Teruyo Tanahashi for her assistance. This study was supported in part by Grant-in-Aid for Scientific Research from the Ministry of Education, Science and Culture, Japan, and by a grant from Miyata Science Research Foundation of Asahi University. 
抄録 : ラット舌下腺の生体膜主要構成成分であるホスファチジルコリン（PC）とホスファチジルエタノー ルアミン（PE）の位直特異性アシル基組成を明らかにした。PC のグリセロール骨格 $s n-1$ 位に結合するア シル基は主としてパルミチン酸, ステアリン酸などの飽和アシル基で， $s n-2$ 位はアラキドン酸，リノール酸 などの不飽和アシル基で構成されていた。同様の非対称的なアシル基分布は PE でも認められた。さらに $\mathrm{PE}$ では, $s n-1$ 位に多量のアルケニル基が認められた。これらの組成から， PC, PE の主要分子種は，各々， 1-パルミトイル-2-アラキドノイル型, および 1-ステアロイル-あるいは1-アルケニル-2-アラキドノイル（プ ラズマローゲン) 型であることが強く示唆された。イソプロテレノールの連続投与は, 耳下腺, 顎下腺リン脂 質中のリノレオイル型リン脂質の著しい増加を引き起こすが, 舌下腺の PC, PE では, sn-1 位, sn-2 位とも に，アシル基組成に変化は認められなかった。

\section{References}

1) Dowd, F., Watson, E. and Suddick, R. P. : Salivary gland metabolism. In: Handbook of Experimental Aspects of Oral Biochemistry (Edited by Lazzari, E. P.) pp. 285-306. CRC Press, Boca Raton, Florida, 1983.

2) Abe, K., Yokota, Y. and Dawes, C.: Effects of parasympathomimetic and sympathomimetic drugs on the secretion and composition of rat sublingual saliva. J. Dent. Res. 61: 52-56, 1982

3) Kameyama, Y., Yashiro, K., Mizuno, M., Okada, A., Takahashi, K. and Yokota, Y. : Comparison of membrane phospholipid and its fatty acid compositions in developing rat salivary glands. Comp. Biochem. Physiol. 87B : 741-746, 1987.

4) Hokin, L. E. : Receptors and phosphoinositide-generated second messengers. Ann. Rev. Biochem. 54 : 205-235, 1985.

5) Putney, J. W., Jr.: Identification of cellular activation mechanisms associated with salivary secretion. Ann. Rev. Physiol. 48: 75-88, 1986

6) Sandermann, H., Jr.: Regulation of membrane enzymes by lipids. Biochim. Biophys. Acta 515 : 209-237, 1978.

7) Aloj, S. M. : Membrane lipids and modulation of hormone receptor expression. In : Hormone Receptors (Edited by Kohn, L. D.) pp. 83-100. John Wiley \& Sons, New York, 1982.

8) Yashiro, K., Kameyama, Y., Mizuno, M. and Yokota, Y.: Alteration of membrane phospholipids in hypertrophied rat salivary glands induced by chronic administration of isoproterenol. Arch. Oral Biol. 32 : 799-805, 1987.

9) Bligh, E. G. and Dyer, W. J.: A rapid method of total lipid extraction and purification. Can. J. Biochem. Physiol. 37 : 911917, 1959.

10) Yashiro, K., Kameyama, Y., Mizuno, M. and Yokota, Y.: Inducing effects of chronic administration of isoproterenol on 1-acyl-snglycero-3-phosphate and 1-acyl-sn-glycero-3phosphocholine acyltransfereases in rat parotid salivary gland. Comp. Biochem. Physiol., in press.

11) Morrison, W. R. and Smith, L. M.: Preparation of fatty acid methyl esters and dimethylacetals from lipids with boron fluoride-methanol. J. Lipid Res. 5:600608, 1964.

12) Mueller, H. W., O'Flaherty, J. T., Greene, D. G., Samuel, M. P. and Wykle, R. L. : 1-O-Alkyl-linked glycerophospholipids of human neutrophils : Distribution of arachidonate and other acyl residues in the etherlinked and diacyl species. J. Lipid Res. 25 : 383-388, 1984.

13) Yoshioka, S., Nakashima, S., Okano, Y., Hasegawa, H., Ichiyama, A. and Nozawa, Y.: Phospholipid (diacyl, alkylacyl, alkenylacyl) and fatty acyl chain composition in murine mastocytoma cells. J. Lipid Res. 26 : 1134-1141, 1985.

14) Bell, R. M. and Coleman, R. M.: Enzymes of glycerolipid synthesis in eukaryotes. Ann. Rev. Biochem. 49 : 459-487, 1980.

15) Kameyama, Y., Yashiro, K., Mizuno, M., Okada, A., Takahashi, K., Hayashi, S. and Yokota, Y.: Comparison of phospholipid synthesis in rat salivary glands: Properties of 1-acylglycerophosphorylcholine and 1acylglycerophosphate acyltransferase systems in microsomes. Comp. Biochem. Physiol., in press.

16) Selye, H., Veilleux, R. and Cantin, M. : Excessive stimulation of salivary gland growth by isoproterenol. Science 133 : 44$45,1961$.

17) Norberg, K. -A. and Olson, L.: Adrenergic innervation of the salivary glands in the rat. Zeitshrift für Zellforschung 68 : 183-189, 1965. 